\title{
A Study on the Role and Effectiveness of Internal Audit in Public Enterprises: The Case of Nekemte City Administration
}

\author{
Tesfaye Eresso Gofe \\ Lecturer, Accounting and Finance Department; College of Business and Economics; Wollega University; \\ Nekemte; Ethiopia
}

\begin{abstract}
Internal audit plays significant role to achieve organizational objectives. Auditors need to be increasingly competent in many different areas in order to do a good job: risk and control analysis, financial analysis, computer technology, etc. An important factor in the professionalization of internal audit is to create a solid ethical climate. Without an ethical environment, laws will never be properly applied, and the legal framework will only be for show. Failure to address key strategic and operational risks as well as compliance risk in an annual audit programs undermines the effectiveness of the Internal Audit Functions. For effective work performance, internal auditors should have the support of top management and the board of directors. Generally, the effectiveness of internal audit function is influenced by human and capital resources available, the scope of internal audit function and the level of interaction with higher management. In most of public enterprise the objectives, authority, scope, and responsibilities of internal auditing are not spelled out due different factors. Internal auditing is handicapped by a critical shortage of appropriately trained and skilled manpower, inadequate organizational status, and a lack of professional independence. The inadequacies in further professional education and the lack of a coordinated comprehensive training program are critical obstacles to strengthening internal auditing. Purposively six public Enterprises were selected from the total sixteen public Enterprises found in Nekemte city administration. Both primary and secondary data were used for Internal Audit to be effective, internal auditors need appropriate competence to achieve their work effectively, and aspects such as education, training, experience and professional qualifications of the internal auditors influence Internal Audit effectiveness.
\end{abstract}

Key words: Audit; Internal Audit; Audit effectiveness; Public enterprises

DOI: $10.7176 / \mathrm{PPAR} / 10-10-04$

Publication date:October $31^{\text {st }} 2020$

\section{INTRODUCTION}

From the very beginning audits are performed to ascertain the validity and reliability of information and also provide an assessment of a system's internal control. The goal of an audit is to express an opinion on the person or organization system in question, under evaluation based on work done on a test basis. Due to practical constraints, an audit seeks to provide only reasonable assurance that the statements are free from material error. Hence, statistical sampling is often adopted in audits. In the case of financial audits, a set of financial statements are said to be true and fair when they are free of material misstatements - a concept influenced by both quantitative and qualitative factors.

Traditionally, audits were mainly associated with gaining information about financial systems and the financial records of a company or a business; see financial audit. However, recent auditing has begun to include non-financial subject areas, such as safety, security, information systems performance, and environmental concerns.

With nonprofit organizations and government agencies, there has been an increasing need for performance audits, examining their success in satisfying mission objectives. As a result, there are now audit professionals who specialize in security audits, information systems audits, and environmental audit.

Internal auditing is an independent appraisal function established within an organization to examine and evaluate its activities as a service to the organization. This statement is more an introduction than a definition. It tells little about what internal auditors are responsible for (Lawrence B. Sawyer, 1996). The nature and scope of the assurance engagement are determined by the internal auditor. Consulting services are advisory in nature, and are generally performed at the specific request of an engagement client.

Internal audit has developed gradually on the bases of social and economic development and the inherent needs of enterprise management (Xingdong, 1997). Similarly, Dittenhofer, (2001) noted that internal auditing is developing as a management process in both private and public sectors. The function aims at providing an independent opinion about whether the objectives of an organization are achieved, and if not to define the circumstance that hinder from accomplishing them (Tatiana et al, 2010).

Thus, internal audit plays significant role to achieve organizational objectives. The Institute of Internal Auditor (IIA, 1999) defines internal auditing as internal auditing is an independent objective assurance and consulting activity designed to add value and improve organization's operations. It helps an organization accomplish its objective by bringing a systematic, disciplined approach to evaluate and improve the effectiveness of risk management, control and governance process The definition signifies that internal auditing is shifted from 
traditional assurance service to consulting and value-adding. To provide the required value-adding service, it is expected to be effective (; Mihret et al, 2010). Hence, effective internal audit function provides the expected valueadding service from the function to the parent organization.

Initially the major role of internal auditing focused on an accounting oriented function that has been gradually transformed into management oriented profession. Previously internal auditors were seen just as an assistant of accountants and an external auditor but recently internal audit is certainly is considered an independent profession, which is playing a significant role in the management of organizations.

One main concern is the degree of independence accorded to internal audit in government structures and organization. As there are still, challenges for to become independent of the executive, independence (structural and financial) for internal audit is yet another step to take. Internal audit must add value to management, while at the same time not becoming its servant, but faithfully report on the status to the board or other equivalent governing body. Besides, Independence of auditors have always been a sensitive issue, especially for internal auditor in which the internal auditor expected to be independent, while he/she is the employees of the organization, above all, not clearly organized structure or reporting line make the problem more complicated. Moreover, the emergence of the concept corporate governance and audit committee brings change in the reporting relationship of internal auditors. In many countries internal audit required to report functionally to audit committee and it is also play key role to assist the board and/or its audit committee in discharging their governance responsibility.

Another major challenge is to professionalize the internal audit function. Auditors need to be increasingly competent in many different areas in order to do a good job: risk and control analysis, financial analysis, computer technology, etc. An important factor in the professionalization of internal audit is to create a solid ethical climate. Without an ethical environment, laws will never be properly applied, and the legal framework will only be for show.

Risk assessment is becoming valuable for success and survival of an organization (William and Kinney, 2003). Regulatory requirements diverted internal audit resources from other important internal audit activities such as risk-based audits to assurance work (Sarens and Beel, 2006). Failure to address key strategic and operational risks as well as compliance risk in an annual audit programs undermines the effectiveness of the Internal Audit Function.

The role of Internal auditing is assuring and consulting organizations but in most organizations they spend most of their time ensuring that accounting records are properly maintained and reliable; that the assets of the enterprises are adequately safeguarded and properly maintained; and that the organization is in compliance with established policies and procedures.

Different study evidenced factor influencing internal audit practice. Among these, Bethlehem (2000), conducted study on Internal Audit Practices, and showed that inefficiency of management commitment, and lacks of developmental programs for internal auditors were critical factors influencing effectiveness of internal audit practice. Mohamed, (2011) conducted study on internal audit and risk assessment in Ethiopian public enterprises and pointed that exclusion of control risk self-assessment to internal audit practice affects audit functions. How ever there are no study conducted on internal audit practice on public enterprise found in Nekemte city administration. Thus, the study will feel the research gap under mentioned.

In most of public enterprise the objectives, authority, scope, and responsibilities of internal auditing are not spelled out due different factors. Internal auditing is handicapped by a critical shortage of appropriately trained and skilled manpower, inadequate organizational status, and a lack of professional independence. The inadequacies in further professional education and the lack of a coordinated comprehensive training program are critical obstacles to strengthening internal auditing. Also, any evaluation of the effectiveness of controls in future periods are subject to the risk that those internal controls may become inadequate because of changes in business conditions, or that the degree of compliance with the policies or procedures may go down.

The present study aims to obtain the opinions of participants regarding the role and effectiveness of internal audit in public enterprises. It introduces a new perspective for the evaluation of internal audit effectiveness by identifying factors that impact on audit effectiveness.

In order to achieve the above intended objective, the following specific objectives are considered:

* To identify the influencing factor towards internal audit purpose, authority and responsibility

$\$$ To assess the independency and report structure of internal audit practice?

* Identifying factors relate to the competence, scope of internal auditing work, and performance of internal auditing work. .

+ To assesses what extent the impact of IT affects IA effectiveness

* To look into internal audit role towards risk based auditing and corporate governance effectiveness

In line with the problem statement raised, the study will try to answer the following research questions.

* What are the influencing factors for effectiveness of internal audit?

\$ To whom does the internal audit unit report in public enterprises?

\# What factors limits the internal audit independency, objectivity, and proficiency?

* How information technology does affect the effectiveness of internal audit? 
How the internal audit risk management and good governance is practiced?

Thus, in view of realization of full value of effective internal auditing, this research study is an attempt of assessing factors influencing the internal audit practices of the public enterprise.

The researcher believes that the result of this research paper will enable the public enterprise governing body i.e. Managers, Team leaders, and Internal auditors to have an understanding of the factors influencing internal audit effectiveness, and try to alleviate these factors to achieve the goal of internal audit practices that helps to meet the objectives set by the public enterprises. The study would be used as an initiation for those who are interested to conduct a detailed and comprehensive study regarding the internal audit practice of Public enterprises.

\section{LITERATURE REVIEW}

In the past, internal auditing was defined as an independent appraisal function established within an organization to examine and evaluate its activities as a service to the organization. This statement is more an introduction than a definition. It tells little about what internal auditors are responsible for. (Lawrence B.Sawyer ,1996).

Accordingly, the new IIA definition of internal audit is as follows: Internal auditing is an independent, objective assurance and consulting activity designed to add value and improve an organization's operations. It helps an organization accomplish its objectives by bringing a systematic, disciplined approach to evaluate and improve the effectiveness of risk management, control, and governance processes. This definition states that scope of internal auditors is assurance and consulting activity. Assurance services involve the internal auditor's objective assessment of evidence to provide an independent opinion or conclusions regarding an entity, operation, function, process, system or other subject matter. The nature and scope of the assurance engagement are determined by the internal auditor. Consulting services are advisory in nature, and are generally performed at the specific request of an engagement client. The nature and scope of the consulting engagement are subject to agreement with the engagement client.

Audits performed by internal audit function are; financial audit for public financial statements, audit of the management information system, operational audit, compliance audit, , IT Audit, , risk assessment and others.

Since the issuance of the COSO Report (COSO, 1992), the intensity of the ties between internal auditing and risk management has increased, as the role of internal auditing has evolved from inspection to risk assessment, thus offering assurance to management and to audit committees that business risks are clearly understood and effectively managed (IIA, 2002-2004; Allegrini and D"Onza, 2003). Internal auditing supports the risk management process throughout the organization by providing tools and techniques for the identification and the evaluation of business risks, by auditing the risk management process and by co-coordinating risk reporting to senior management (IIA - UK and Ireland, 2002).

As per Danescu (2008) Risk Based Internal Audit is driven by risks and reports whether these are managed, the focus being on managing the future. Risk Based Internal Audit is targeted on: risk identification, prioritization of audit area and allocation of audit resources in accordance with risk assessment.

Management support is another critical factor that enhances IA effectiveness. In order for the internal audit department to be effective, the support of top management is absolutely critical. Boyle (1993) finds that the support of IA by top management was identified in his interviews as a critical validation of the fact that internal auditors should perform their work effectively. Mihret and Yismaw (2007) and Mihret and Woldeyohannis's (2008) studies in Ethiopia state that management support to IA is considered as a determinant of IA effectiveness. According to Mihret (2009), management support to IA is identified as one of the factors that bode well for a good IA department profile. In addition, Zain, Subramaniam and Stewart (2006) indicate that with the appropriate level and type of resources directed to the internal audit function, firms should subsequently reap the benefits in terms of the internal audit function aiding and supporting the external audit. Albercht et al. (1988) state that there are four factors that IA directors could develop to enhance IA effectiveness, namely: top management support; an appropriate corporate environment; high quality internal audit staff; and an appropriate corporate environment.

The authors also highlight that the visible support of top management to the internal audit department may be the single most important factor that enhances IA effectiveness.

For effective work performance, internal auditors should have the support of top management and the board of directors. Management support is also important for an internal audit department to monitor management risk.. Furthermore, top management support is crucial to the success of a variety of initiatives. Top management support is shown by the motivation provided by top management to internal auditors.

Mihret and Yismaw (2007) state that autonomy on budgets is another sub factor relating to the organizational setting, as it entails resource implications. They find that the internal audit office of the university is not a budget center, and evidence from interviews and questionnaire responses indicate this lack of authority for budget administration adversely influences performance of the internal audit office.

Another form of management support lies in financial support in terms of bonuses and recompense. It could be argued that management support in terms of these financial incentives for the internal auditor staff motivates staff to work in this area and be more effective. In this connection, for example, Muller-Peters, Kern and Geibler 
(2001), cited in Göritz (2004), recruited members for a commercial market research panel through personal interviews and the authors established that $52 \%$ of interviewees who were offered the incentive had expressed an interest in becoming panelists and subsequently signed up.

Burns, Greenspan and Hartwell (1994) find that management is more likely to comply with internal auditor recommendations and that an organization's internal auditors may enjoy a certain cruciality 'if senior management is externally motivated to follow the recommendations of the internal audit department. Without such motivation, the internal auditor may not be in a position to influence management when management's actions are inappropriate. It appears that management's acceptance of the internal auditors recommendations may enhance IA effectiveness. Therefore, the internal audit department may not be able to adequately and effectively achieve their work without the appropriate support of the body it is responsible to, whether this support is moral through the sufficient authorities vested in it or physical through the availability of all its needs. It appears that strong top management support, communicated throughout the company, is an absolute necessity in order to achieve IA effectiveness.

\section{EMPIRICAL EVIDENCE}

The effectiveness of internal audit function is influenced by organizational setting, management support, internal audit quality, audit attributes and the interplay among them (Mihret and Yismaw, 2007). Thus, the favorability of the four factors positively influences the effectiveness of the internal audit function.

Similarly, Arena and Azzone, (2009) noted that effectiveness of internal audit function is influenced by resources and competencies of an internal audit team, activities and processes performed and organizational role. Generally, the effectiveness of internal audit function is influenced by human and capital resources available, the scope of internal audit function and the level of interaction with higher management.

Different studies have been conducted to determine internal audit effectiveness, the characteristics of internal audit department and the value adding role of internal audit function (see for example Arena and Azzone, 2009)

Arena and Azzone (2009) conducted a survey study in 153 Italian companies to understand the organizational drivers of internal audit effectiveness. The result revealed that internal audit effectiveness is influenced by: the characteristics of the IA team, the audit processes and activities, and the organizational links. The effectiveness increases in particular when; the ratio between the number of internal auditors and employees grows, the Chief Audit Executive is affiliated to the Institute of Internal Auditors (IIA), the company adopts control risk selfassessment techniques, and the audit committee is involved in the activities of the internal auditors.

Michael et al., (2007) studied process model of internal auditing. The purpose was to investigate and understand the reasons why internal auditing is often perceived to not add value. It was based on process analysis, identified areas of potential inefficiency and conflict. The literature review identified the standards and guidance that influence the way internal auditing is managed and its current trends

Questionnaire was sent to auditors and auditees, to gain their views on audit effectiveness and quantify their perception of value. The finding reveals that variations exist in the perceived value of internal auditing, particularly of some key stages in the process. The management of internal auditing is too focused on programmed achievement, not the resulting value from improvement action. This study focused on the value adding practice of internal audit. This on the other hand is influenced by the effectiveness of the function.

Mihret and Yismaw, (2007) conduct a case study research. The purpose of the study was to identify factors impacting the effectiveness of internal audit services in Ethiopian public enterprise by employing a case study design. The findings suggest that management support and internal audit quality have significance influence on the effectiveness of the function. The researchers conclude that, there is a limited effectiveness in the case organization. However, this study was conducted before the implementation of internal audit reengineering in Ethiopian public enterprises. The reengineering has been implemented in order to improve the performance of the function.

In addition Mihret and Woldeyohannis, (2008) conducted a case study research in an Ethiopian public enterprise. The purpose of the study was to draw inferences on how the attributes of a value adding internal audit department would vary among organizations. The finding reveals that the traditional/ compliance audit is dominant in the organization under study contrast to value-added auditing. The study concluded that goals and strategies pursued and the level of risk faced by organizations to which internal audit provides service, appears to shape the attributes a value adding internal audit department. The study also demonstrates that the quality of strategic planning for and marketing of internal audit would influence the extent to which an appropriate value-added profile is attained in a particular context. This study assessed the value-adding role of internal audit function in an Ethiopian public enterprise. The value adding role of internal audit function is determined by the perception of auditees and internal auditors. Internal audit effectiveness on the other hand, stands for the functions capability to achieve the functions objectives

Fadzil et al (2005) find that scope of audit work significantly influences the information and communication aspect of the internal control system. A system of internal control consists of policies and procedures designed to 
provide management with reasonable assurance that the business entity achieves its objectives and goals.

\section{METHODOLOGY OF THE STUDY}

The type of research which is being employed in this research is descriptive type, describing the characteristics of a particular individual in this case the researcher must able to define what he want to asses and find adequate methods of measuring it along with a clear cut definition of population the researcher wants to study. Accordingly, this method is selected, because it would be convenient for the purpose of examining the practice of internal audit in public enterprises. The study considered both qualitative and quantitative research approach. Both primary and secondary data were used. The populations considered in this study were all public Enterprises found in Nekemte city administration. As per trade and industry office of Nekemte city administration of the year 2015, there are sixteen public enterprises. Each public enterprise constitutes finance head, managers \& internal auditor, human resource and other employees. Purposively six public enterprises were selected. The researcher selected public enterprise based on scope of internal audit, focusing on internal audit function and internal auditing activities they provide than others. From the selected public enterprise the researcher purposively had taken internal auditors, heads of finance, human resource, property management and the top managers.

Accordingly, depending on the sampling technique stated the study selected six public enterprises. These are: Telecom, Ethiopian Electric Power Corporation (HEPCO), Commercial Bank of Ethiopia (CBE)), Ethiopian Insurance Company (EIC), Construction \& Business Bank and General Trade importer Institutions. A sample size included in the study were all internal auditors, Team leaders of finance, human resource and property management and managers of each selected public enterprise. Thus 18 questionnaires' were distributed to internal auditors and 50 questionnaires to others. The sample size of the study was totally 68 . The gathered data was interpreted, analyzed and discussed. The data collected were edited, coded, and presented. The collected data were processed by using statistical software called SPSS 16.0 version. The analysis of data also is through different statistical tool like mean, mode, percentage median standard deviation, etc. The data was presented by the use of charts, graphs and some other statistical techniques.

\section{RESULT AND DISCUSSIONS}

Two types of questionnaires were prepared for the internal auditors and other employee so as to harvest more information on important issues which are very relevant to the research objective.

\begin{tabular}{llcrcr} 
& & Questionnaire Distributed and Collected & \\
\hline No. & Questionnaire & Respondents & \multicolumn{3}{c}{ other Employees } \\
& & Internal Auditors & $\%$ & No & \% \\
& & No & 100 & 50 & 100 \\
$\mathbf{1}$ & Distributed & 18 & 94.4 & 46 & 92 \\
$\mathbf{2}$ & Collected & 17 & 5.6 & 4 & 8 \\
\hline 3 & Uncollected & 1 & & \\
\hline
\end{tabular}

As it can be seen from the, 50 questionnaires to other employees and 18 questionnaires to internal auditors of Nekemte town public enterprises were distributed; only around 17 of them from Auditors and 46 of them from employees were collected. This is sufficient response rate because more than $90 \%$ of the questionnaires were collected and used for the analysis. About $5.56 \%$ of the questionnaires from internal auditors and $8 \%$ of them from other employees were not collected due to the reluctance of the respondents. Thus, only $17(94.4 \%)$ of questionnaires from internal auditors and 46(92\%) of questionnaires from other employees were used for the analysis. Some respondents did not respond some questions of the questionnaire for either they overlooked or the questions do not concern them and in the analysis part they are reported as "Unspecified". Questionnaires were distributed to all the auditors. Interviews were conducted with the managers as mentioned above to support the results.

\section{Demographic Characteristics}

Demographic factors are the most indicators of performance. Thus, in this research the demographic characteristics of respondents like sex, age, marital status Experience and educational level are emphasized. Regarding to Sexes of respondents about $70.59 \%$ of the respondents was male while about $29.41 \%$ of them were female. This notifies that more than half of the internal auditors were male. From this we can concluded that the participation of females' employees was low in internal audit department compared to males.

As noted, a number of prior studies have found that experience impacts on the ethical decision making of internal auditors. However, the direction of the relationship is ambiguous. In an experiment on working paper review, Bernardi (1994) found that managers outperformed seniors with respect to identifying ethical cues. This study also examines how audit experience affects the development of auditors' client business knowledge. Thus, 
to investigate the related research questions, it was necessary to have auditors with varying amounts of audit experience complete the study.

According to survey result $52.94 \%$ of employee having experience as auditors 3-5 years' experience and $35.29 \%$ of employee have experience of 5-10years in addition $35.29 \%$ of employee have experience of 1-3 years' experience. In general internal audit work requires experience on a wide range of systems and operations. As it is indicated above, one can understand that almost half of the auditors have less than 6 years of experience working in the auditing profession. This shows that much of the respondents are not well experienced working as an auditor

IIA states that the purpose, authority, and responsibility of the internal audit activity should be formally defined in a charter, consistent with the standards, and approved by the board. Again, implementation IIA standard states that the nature of consulting services should be defined in the audit charter. In addition to the availability of the internal audit charter that clearly states the purpose, authority and responsibly of the IAF in each of the public enterprise, the internal audit charter should be effectively communicated to the respective internal auditors.

Being one of the very essential elements of internal auditing, audit charter needs to be available and clearly understood by the people in action. According to survey result $5.88 \%$ of the respondents reply that there is no audit charter and 5.88\% answered that they have no information about the availability of audit charter in their organizations. Most of the respondents $88.24 \%$ respond instead of audit charter uses government manual. This implies that the audit charter is not present in those organization instead used only government manual.

In this respect, the researcher tries to analyze two different subject matters: internal auditor's hierarchy and reporting line of the internal audit function based on the analysis more majority of respondents said that their unit is responsible for Top management of the organization which consists of $82.35 \%$ of the respondents. $11.76 \%$ of respondents said that internal auditor's periodically report to board of directors. The remaining 5.88\% of respondents said that they report to line management.

The result shows that there was no good communication of internal audit findings with top management. It indicates that in the view respondents there exists no follow-up practice for implementation of corrective actions related to audit findings.

\section{Types of auditing}

The survey also aimed at analyzing planned annual auditing activity is devoted to (in percentage) the following audit types: Financial audit for public financial statements, Operational audit, Compliance audit, performance audit and IT Audit

\begin{tabular}{llrrrr}
\hline No & \multicolumn{1}{c}{ TYPES OF AUDIT } & \multicolumn{2}{c}{ N } & Mean & Std. Deviation \\
\cline { 3 - 3 } & & Valid & Missing & & \\
$\mathbf{1}$ & Financial audit & 17 & 0 & 2.3529 & .93148 \\
$\mathbf{2}$ & Performance audit & 17 & 0 & 3.7059 & .98518 \\
$\mathbf{3}$ & Compliance audit & 17 & 0 & 2.9412 & 1.14404 \\
$\mathbf{4}$ & IT Audit and Fraud investigation & 17 & 0 & 4.0000 & .79057 \\
\hline
\end{tabular}

The scope of internal audit service was assessed in asking questions. From the total of 4 questions; questions had mean responses of less than 3.00. This implies that in the view of respondents, internal audit function often perform those activities. Those questions were focused on financial performance and compliance audit activities. The standard deviation of question 3 was more than 1.00 -which indicates that the perceptions ${ }^{\text {ee }}$ of respondents were far from one another. The scope of internal audit generally regards the suitability of procedures from the perspective of economy, effectiveness, and efficiency. Generally it was found that most organization applies financial audit and compliance audit type. Public enterprise internal audit guide line require all of audit activities listed above to be performed, but many public enterprises specially smaller one were performed compliance and Financial audit in their annual audit activities. However, the auditors are not engaged in the full range of activities as might be expected by professional standards, e.g. auditors are not involved in the audit of IT audit.

\section{Audit planning}

Planning is generally considered a vital audit activity and it includes preparing annual plans and programs for individual audit assignments. The operational standard No. 500 of the Internal Audit Standard of the Government of Ethiopia, dealing with the planning aspects of the internal audit, requires the preparation of a strategic plan usually a five-year plan, a periodic (annual) plan and plans for individual audit assignments.

The results revealed that the audit planning practice in Nekemte city administration public enterprise was assessed. 29.41\% of the respondent's reveals that the annual audit plan is prepared and it is based on risk assessment and. $58.82 \%$ shows audit plan is prepared according to request of top management. Only $11 \%$ of the respondent's reveals that by considering the resources available. This implies that, in the view of respondents, the annual audit plan is prepared by request of top management. The results revealed that internal audit function use all three approaches to plan its annual audit, but request of top management approach is the most important as compared to risk based and control based approach. 


\section{Management support}

Management support is one of the most important factors influencing audit practice. As the response indicates, the auditors feel that the public enterprise does not sufficiently utilize audit reports. All the respondents replied that the management's response to the internal audit findings and recommendations is generally not adequate. This would have far reaching implications on the auditor's attitude towards improving audit quality, their commitment to develop a career as internal auditor in the public enterprise and their job satisfaction.

The responses to questionnaires reveal that $58.8 \%$ of the respondents say low support of management and $23.5 \%$ of them says very low commitment of management's $.5 .9 \%$ of them responds neutral and only $11.8 \%$ of the respondents say high commitment of management there. The result shows low response to audit findings and recommendations from the management side.

Interviewees reported that internal audit suffers from a lack of support from top management. Resistance to the establishment of internal audit has created a negative attitude towards internal audit and consequently, low levels of support. Several reasons were offered for the perceived absence of management support. These included: ignorance on the part of top level management regarding the importance of the internal audit role and lack of attention paid thereto; the organizational status of internal audit which consequently affected its independence; and general organizational resistance to the idea of establishing an internal audit function.

\section{Corporate Governance}

Hermanson and Rittenberg (2003) noted that IAF plays a unique role in the governance process; and Paape, et al. (2003) added that in the slipstream of current developments, legislations, rules, regulations and guidelines coming from many directions organizations, rather than the individual decisions of this or that company, board or committee, IA is most likely going to be viewed as an important and even integral element of the corporate governance system. "internal auditors check compliance with laws and regulations", median and mode responses were 5.00 and this were supported by interviews and documents review result that one duty of internal auditors is checking of activities compliance with laws and regulations. This indicated that IAF exhibited a high profile in checking compliance with laws and regulations which conforms to the concept that IA reviews the compliance framework and specific compliance issues to deliver service to other parties of corporate governance to discharge their governance responsibilities (KPMG, 2003). Moreover, Mihret and Woldeyohannis (2008) in their case study research on the value-added role of internal auditing revealed that compliance auditing shares most of the auditors ${ }^{\text {ee }}$ time in their audit activity.

\begin{tabular}{|llrrrr}
\hline No & GAVERNANCE & \multicolumn{2}{c}{$\mathbf{N}$} & Mean & \multicolumn{1}{c}{$\begin{array}{c}\text { Std. } \\
\text { Deviation }\end{array}$} \\
\cline { 3 - 3 } $\mathbf{1}$ & $\begin{array}{l}\text { Internal auditors check the adequacy of record keeping } \\
\text { when appropriate }\end{array}$ & 17 & 0 & 2.8824 & 0.85370 \\
$\mathbf{2}$ & $\begin{array}{l}\text { Internal auditors check compliance with laws and } \\
\text { regulations }\end{array}$ & 17 & 0 & 2.0588 & .74755 \\
\hline $\mathbf{3}$ & $\begin{array}{l}\text { Internal auditors assess the accomplishment of corporate } \\
\text { objectives }\end{array}$ & 17 & 0 & 4.0588 & .74755 \\
\hline $\mathbf{4}$ & $\begin{array}{l}\text { communicating risk and control information to areas of the } \\
\text { organization }\end{array}$ & 17 & 0 & 3.8824 & .85749 \\
\hline
\end{tabular}

\section{Source: Questionnaire results}

The governance was assessed in question 1 up to question 4 . The first two questions focused on governance and questions had mean responses of less than 3.00 and standard deviation of less than one. This implies that in respondents perceptions were closed to each other. Internal auditors check the adequacy of record keeping when appropriate and Internal auditors check compliance with laws and regulations. However; the second two questions had mean responses of greater than 3.00 and standard deviation of less than one. This implies that that respondent's perceptions were closed to each other. It implies that most internal auditors were not assess the accomplishment of corporate objectives and communicating risk and control information to areas of the organization.

Supplementary, interview and document review results also revealed that IAF checks the effectiveness and efficiency, and accomplishment of objectives of the organization. These results imply that internal auditors of the organization have no much key roles in delivering the services to maintain strong corporate governance that corroborates to the literature that IA "s key role is to assist the top management in discharging their governance responsibilities by delivering assessments of the accomplishment of corporate goals and objectives.

\section{Challenges of computer technology}

The rapid changes caused by the continuous introduction of new computer technology have made the internal auditor's job more complex. Typical computerized applications of the 1990s incorporate, and are developed using, advanced methodologies and techniques. These applications may be decentralized and may have distributed databases. Telecom and banks are becoming an integral part of computerized applications and many of these will 
be designed in conjunction with the use of innovative technology.

\begin{tabular}{|c|c|c|c|c|c|c|c|}
\hline & \multicolumn{7}{|c|}{ Statistics } \\
\hline & \multirow{2}{*}{$\begin{array}{l}\text { Responding to the challenges of } \\
\text { computer technology }\end{array}$} & \multicolumn{2}{|r|}{$\mathrm{N}$} & \multirow[t]{2}{*}{ Mean } & \multirow{2}{*}{$\begin{array}{c}\text { Std. } \\
\text { Deviation }\end{array}$} & \multirow[t]{2}{*}{ Minimum } & \multirow[t]{2}{*}{ Maximum } \\
\hline & & Valid & Missing & & & & \\
\hline 1 & $\begin{array}{l}\text { Internal audit staff have qualifications } \\
\text { for auditing computer technology } \\
\text { systems }\end{array}$ & 17 & 0 & 3.7059 & 1.10480 & 2.00 & 5.00 \\
\hline 2 & $\begin{array}{l}\text { Internal audit staff uses computer } \\
\text { technology is being as an audit tool in } \\
\text { actually performing the audits. }\end{array}$ & 17 & 0 & 3.7647 & .66421 & 2.00 & 5.00 \\
\hline 3 & $\begin{array}{l}\text { We found that, in several } \\
\text { departments, internal audit provide } \\
\text { adequate audit coverage of EDP } \\
\text { systems; }\end{array}$ & 17 & 0 & 4.0588 & .65865 & 3.00 & 5.00 \\
\hline 4 & $\begin{array}{l}\text { Internal audit staff did effectively use } \\
\text { computers to improve audit } \\
\text { productivity; }\end{array}$ & 17 & 0 & 3.2353 & 1.14725 & 1.00 & 5.00 \\
\hline 5 & $\begin{array}{l}\text { Internal audit staff have the internal } \\
\text { computer audit skills } r \text { to carry out } \\
\text { major computer audits }\end{array}$ & 17 & 0 & 4.0000 & .79057 & 2.00 & 5.00 \\
\hline
\end{tabular}

The result in the table (a table under Challenges of computer technology) indicated that respondents on practice of computer technology in internal auditing on questions focused on practice of computer technology in internal auditing questions had mean responses of greater than 3.00 and standard deviation of less than one. The Standard deviations of the first and fourth questions were more than 1.00, which implies some internal audit staff have qualifications for auditing by computer technology assessment, and effectively use computers. This implies that those respondents' perceptions were far away from each other

In this study of best practices in internal audit, the researcher saw how developments in technology have increasingly affected internal audit. In reaching this conclusion, it is looked at the scope of audits of information systems, the staff qualifications for auditing these systems and the extent to which computer technology is being used as an audit tool in actually performing the audits. It is observed that, in several departments, internal audit: did not provide adequate audit coverage of EDP systems; did not effectively use computers to improve audit productivity; and did not have the internal computer audit skills either to carry out major computer audits or to supervise the work of EDP audit consultants. From this it can conclude that ineffectiveness of IA on EDP resulted in ineffectiveness of IA.

\section{Staffing and training}

To implement the audit, the auditors' diploma or degree is not sufficient; getting well trained auditors with strongly built skills is the urgent need of the corporation. Only then can the auditors play the desired role. Investing in training has a paramount importance. Therefore, the organizations should have sound budget to train its auditors, be it in-house or external as necessary. New approach to staffing that uses the training and development potential of internal audit will likely result in staff who bring a different mix of skills to their work. Staff with only technical audit skills will become less prevalent. By contrast, those with program-related knowledge, a broad management perspective and specialized skills such as information management and technology will become more common. 
Staffing and Training of internal auditors

\begin{tabular}{|llrrrrrr}
\hline No & \multicolumn{1}{c}{ Staffing } & Valid & Mean & $\begin{array}{c}\text { Std. } \\
\text { Deviation } \\
.79057\end{array}$ & Minimum & Maximum \\
$\mathbf{1}$ & $\begin{array}{l}\text { Internal auditors have the chance to } \\
\text { attend either training programs or } \\
\text { conference }\end{array}$ & 17 & 0 & 4.00 & & 5.00 \\
$\mathbf{2}$ & $\begin{array}{l}\text { The contribution of the top } \\
\text { Management for training via } \\
\text { enhancement of }\end{array}$ & 17 & 0 & 3.8235 & .72761 & 2.00 & 5.00 \\
$\mathbf{3}$ & $\begin{array}{l}\text { auditors' technical and professional } \\
\text { knowledge is high } \\
\text { the organization have sound budget } \\
\text { to train its auditors }\end{array}$ & 17 & 0 & 3.7059 & .77174 & 2.00 & 5.00 \\
\hline $\mathbf{5}$ & $\begin{array}{l}\text { number of staff is sufficient in you } \\
\text { organization }\end{array}$ & 17 & 0 & 4.00 & .70711 & 3.00 & 5.00 \\
$\mathbf{6}$ & $\begin{array}{l}\text { Internal auditor leave the } \\
\text { department via transfers to other } \\
\text { departments in the organization }\end{array}$ & 17 & 0 & 4.1176 & .78121 & 2.00 & 5.00 \\
\hline
\end{tabular}

The staffing and training was assessed in questions focused on training and had mean responses of greater than 3.00 and standard deviation of less than one. This implies that that respondent's perceptions were closed to each other. In addition the question focused on training and questions had mean responses of greater than 3.00 and standard deviation of less than one. This implies that respondent's perceptions were closed to each other. The figure evidence indicated that as a result of high-staff turnover auditors leave the department via transfers to other departments in the organizations; on the other hand, transfers into the internal audit department are significant. This results in more new recruits in the department, which adversely impacts the effectiveness of internal audit. In addition, the number of staff is not sufficient, given the large size and complexity of the organization activity.

Responses to open-ended questions in the questionnaire revealed that the auditors view the office as given insufficient attention in terms of staffing. Training analysis of the figure data revealed that there is a shortage of training programs and too few opportunities to attend such training that did exist. To take an example, one interviewee said: several reasons for the lack of training, including financial issues (example, the amount allocated for training staff), shortage of internal audit-related programs available to internal auditors. The above comment and the responses to the questionnaires indicate that the level of training given to auditors is low.

\section{Attitude of employees towards Competence of internal auditors}

For IA to be effective, internal auditors need appropriate competence to perform their work satisfactorily (Burnaby et al. 2009). Technical competence and continuous training are considered essential for effective internal audit‘. Libby and Frederick (1990) indicate that experience is an important tool in enhancing auditors 'knowledge. Internal auditors require a wide range of competencies to achieve satisfactory performance in the various hierarchical positions within internal audit departments to audit different department in the organization. Competence requires knowledge and professionalism that the auditor should acquire from education, on-the-job training, and experience. This view is supported by Flesher and Zanzig (2000) who indicate that internal audit departments should have internal auditors who possess a variety of skills to enable them to undertake audits of areas beyond financial activities.

\section{INTERNAL AUDITORS COMPITENCY}

1 Internal auditors possess appropriate knowledge to audit your department

2 Educational level

3 Internal auditors ascertain your department's compliance with organizational policies and procedures

4 The existence of internal audit assists efficient use of resources in the organization

5 Internal auditors possess understand your department

\begin{tabular}{rrrr}
\multicolumn{2}{c}{$\mathbf{N}$} & Mean & \multicolumn{1}{c}{$\begin{array}{c}\text { Std. } \\
\text { Deviation }\end{array}$} \\
\cline { 1 - 2 } Valid & Missing & & .694 \\
46 & 0 & 4.09 & .437 \\
46 & 0 & 2.17 & .701 \\
$\mathbf{4 5}$ & 1 & 4.09 & .67 \\
46 & 0 & 4.15 & .470 \\
46 & 0 & 4.02 & .683
\end{tabular}

The questions were distributed to respondents to assess the competence of internal auditors in the organization. The mean responses were above 4.00 for all questions except the second question which shows mean response of 
2.17 indicating auditors are in good Educational level. This reveals that in the perception of respondents, that they are not competent. The standard deviation of the second \& fourth was less than 1.00 -which indicates that the perceptions of respondents were close to one another.

\section{Employee Support towards Internal Audit Effectiveness}

For IA to be effective, internal auditors need appropriate competence to perform their work satisfactorily. Staff is vital to the effective operation of IA, and that unless they possess the necessary competencies the power of internal auditors may be diminished. Staff will support by giving important information for auditors that effectively contribute to the achievement of organizational goals; internal auditors who are familiar with the organization under audit are in an ideal position to provide information. For example if information concerning a perpetrated fraud is passed on to internal audit well in advance, this fraud will be prevented from occurring. In this way the employee will have shown form of good manners and supported internal audit by rendering information, which contributes to risk management by way of preventing a loss from occurring, thus indirectly contributing to effectiveness of internal audit function.

The prevention, deterrence and detection of fraud are the responsibility of management. The usual role of internal auditors is to develop audit programs and procedures to evaluate the internal controls that management has established to manage the risk of fraud. In practice auditing sometimes prevent employees from committing fraud and occasionally detects a fraud, but these is applicable if employees support them

Thus staff commitment as being linked to positive behavioral intentions under control of individuals and are important components in achieving organizational objective. This means that as more of support to internal audit function will be realized which will ensure effective audit, in turn, enabling achievement of objectives.

\section{CONCLUSIONAND RECOMMENDATION}

This implies that the higher the level of acceptability of internal audit functions, the more support internal audit function will receive from management and staff. Therefore management needs to create an environment that will harness commitment and support to internal audit if it is to effectively perform its responsibility of giving assurance that organizational risks are effectively managed. This will only be possible if individuals within organizations are aware of the role and importance of internal audit function. Therefore organizations sensitizing of staff about the role of internal audit is also necessary performance may influence. Such acts of appreciation, if interpreted as management support by the internal auditors, can influence them to perform conscientiously positively impacting on their effectiveness. This means that the more, individuals are willing to exhibit extra-role behaviors in organizations, the more they will render support to internal audit function. Individuals who are willing to exhibit extra-role behaviors for the good of the organization are prone to render support to internal audit function in their process of assisting organizations manage risks. This support will be manifested through those extra role behaviors. For example if information concerning a perpetrated fraud is passed on to internal audit well in advance, this fraud will be prevented from occurring. In this way the employee will have shown form of good manners and supported internal audit by rendering information, which contributes to risk management by way of preventing a loss from occurring, thus indirectly contributing to effectiveness of internal audit function.

The findings of the study revealed that internal audit department needs to enhance the proficiency of IA such as; training, experience and professional certification so as to foster the quality of IAF and in turn to has positive impact internal audit effectiveness, for the reason that audit quality significantly influences audit effectiveness. Management's commitment to taking timely corrective action to IA recommendation and hiring of well qualified employees is a proxy for the quality of IAF. Hence, management of needs to improve these issues to have quality IAF and its positive impact on audit effectiveness. Moreover, the researcher recommends that to receive the multiservices which delivered by IAF (or assurance and consulting services) and contribute to the effectiveness of audit, management of the organizations should recognize and implement IA activities and reports, in view of the fact that that rate of implementation of audit recommendation by management is indicative of IA effectiveness (Mihret \& Yismaw, 2007).

Future research should also focus on IAF role in corporate governance effectiveness in other sectors to add to the existing knowledge and to evaluate the practices of IA activity. It is suggested that internal auditors train employees regarding the accurate handling of resources in order to increase effective and efficiency of economic use of resources and value creation.

When internal auditors have professional proficiency such as adequate knowledge, professional membership, certification and training in electronic data processing systems, it would imply that they are competent. Based on this understanding, For IA to be effective, internal auditors need appropriate competence to achieve their work effectively (Burnaby \& Hass 2009), and aspects such as education, training, experience and professional qualifications of the internal auditors influence IA effectiveness (Al-Twaijry, Brierley \& Gwilliam 2003). It is therefore recommended that:

* Additional staff with audit experience be employed to augment the staff strength. 
\# Staff should be motivated through strategies such as effective feedback systems, self-fulfillment,

* There should be effective staff training and development programs

* The department should be evaluated for its efficiency, effectiveness and economy.

Training to provide staffs who do not have an audit background with knowledge of audit standards, principles and ethics and with the requisite technical audit skills will be essential

The most frequently cited reason that is ranked first by respondents is inadequate management support for the office.

In our study of effectiveness of internal audit, we saw how developments in technology have increasingly affected internal audit. Most internal audit will have to change their audit approaches and use technology more and more to improve both their service and the quality of their audits. However, the study found that internal audit in the federal government has met the challenge of playing an effective role in auditing these systems. As a result improvement is needed to eliminate these weaknesses. Specifically, internal audit must acquire and maintain EDP audit skills and develop and use methodology for auditing computer systems. It must also learn to use technological tools to increase the productivity of its audits.

\section{REFERENCES}

* Abdolmohammadi, MJ \& Sarens, G (2009), Cultural Dimension as an Explanatory Variable in Use and Compliance with Internal Auditing Standards in Nineteen Countries.

* Adams, MB (1994), 'Agency Theory and the Internal Audit', Managerial Auditing Journal, vol. 9, no. 8, pp. $8-12$.

* Agoglia, CP, Kida, T \& Hanno, DM (20030, 'The Effects of Alternative Justification Memos on the Judgments of Audit Reviewees and Reviewers', Journal of Accounting Research, vol. 41, no. 1, pp. 33-46.

* Ahlawat, SS \& Lowe, DJ (2004), 'An examination of internal auditor objectivity: In-house versus outsourcing', Auditing: A Journal of Practice and Theory, vol. 23, no. 2, pp. 149-60.

* Al-Twaijry, AAM, Brierley, JA \& Gwilliam, DR (2003); 'The development of internal audit in Saudi Arabia: An institutional theory perspective', Critical Perspectives on Accounting, vol. 14, no. 5, pp. 507-31. ---- 2004, Argaw, L (1997), ' Internal Auditing in Ethiopia: Past, Present and Future', The Ethiopian Journal of Accountancy \& Finance, vol. 1, pp. 1-32. 210

* Bonner, S. E., and B. L. Lewis (1990). Determinants of auditor expertise. Journal of Accounting Research 28(Supplement): 1-20.

* Bonner, S. E., and N. Pennington (1991). Cognitive processes and knowledge as determinants of auditor expertise. Journal of Accounting Literature 10: 1-50.

* Bonner, S. E., and P. L. Walker (1994). The effects of instruction and experience on the acquisition of auditing knowledge. The Accounting Review 69(1): 157-178.

* Creswell, JW. (2009), 'Editorial: Mapping the field of mixed methods research`, Journals of Mixed Methods Research Vol.3, No.95, pp.95-109

* Creswell, W.J. (2003), Research Design: Qualitative, Quantitative and Mixed approaches, 2nd ed., New Delhi: Sage.

* Enyue, Z (1997), 'Development trends of internal auditing in China', Managerial Auditing Journal, vol. 12, no. 4,5, pp. 205-09.

* Flesher, DL \& Zanzig, JS (2000), 'Management accountants express a desire for change in the functioning of internal auditing', Managerial Auditing Journal, vol. 15, no. 7, pp. 331-7.

* Gramling, A.A (2004). "Role of Internal audit function in corporate governance, a synthesis of the extent internal auditing literate and directions for future research" journal of Accounting literature, Vol. 23, pp.26378.

* Goodwin, J.(2004), 'A comparison of internal audit in the private and public sectors', Managerial Auditing Journal, Vol.19, No.5, pp. 640-650.

* Goodwin, S.J. and Kent, P. (2006), “The use of internal audit by Australian companies”, Managerial Auditing Journal, Vol. 21 No. 1, pp. 81-101.

* Institute of Chartered Accountants - Guidance for Audit Committees. The Internal Audit Function March 2004. http://www.icaea.co.uk

* Internal Audit Division, OIOS(2009) the Internal Audit Manual ,International Standards for the Professional Practice, pp. 28-62

* Institute of Internal Auditors. (2004) The Role of Internal Auditing in Enterprise - Wide Risk Management.

* Institute of Internal Auditors (2004). The professional Practices Framework. Altamonte Springs FL. The Institute of Internal Auditors

* Institute of Internal Auditors (IIA) (2000). Administrative directive No. 4: 2000: continuing professional education (CPE) requirements. Florida: the IIA. 
* Institute of Internal Auditors (IIA) (2006). The role of auditing in public sector governance. Florida: the IIA.

* Gallegos et al (2004), Information Technology Control and Audit, 2nd Ed, Aurebach publications CRC press LLC.

* James K (2003). The Effect of internal audit structure on perceived financial statements fraud prevention. Account. Horizons 17(4):315-327.

* Leung P, Cooper B, Robertson P (2003). The role of internal audit in corporate governance. The Institute of Internal Auditors Research Foundation, RMIT University Melbourne.

* Leung P, Cooper B, Robertson P (2004). Role of internal audit in corporate governance and management. RMIT University, Melbourne.

* Lewington D (1996). 2020 Vision. Managerial Auditing J. 11(7):3-11. Loss J (2000). The communication contract. The Internal Auditor 57(6):88.

* Maher M, Akers M (2003). Internal audit"s role in system development: the CEO's Perspective. Internal Auditing 18(1):35-39.

* Marnet O (2008). Behaviour and rationality in corporate governance. Routledge, London and New York.

* Messier W, Reynolds J, Simon C, Wood D (2011). The effect of using the internal audit function as management training ground on the external auditor's reliance decision. Account. Rev. 86(6):2131-2154.

* Mihret D (2010). Factors associated with attributes of internal audit departments: a canonical analysis. Afr. J. Account. Econ., Financ. Bank. Res. 7(6):42-61.

* Mihret D, Yismaw A (2007). Internal audit effectiveness: an Ethiopian public sector case Study. Managerial Auditing J. 22(5):470-484.

* Myers M, Gramling A (1997). The perceived benefits of certified internal auditor designation. Managerial Auditing J. 12(2):70-79.

* Nagy A, Cenker W (2002). An assessment of the newly defined internal audit function.

* Managerial Auditing J. 17(3):130-137. Paape L, Scheffe J, Snoep P (2003). The Relationship between the internal audit function and corporate governance in the EU-a survey. Int. J. Auditing 7(3):247-62.

* Kagaari J., Munene J.C., and Ntayi J.M., (2010) Performance Management Practices,Employee attitudes and Management Performance and International Journal of Human Resource Management Vol. 5 No 2, pp. 301326

* Kalbers, LP \& Cenker, WJ 2007, 'Organizational commitment and auditors in public accounting', Managerial Auditing Journal, vol. 22, no. 4, pp. 354-75.

* Kerlinger, FN \& Lee, HB 2000, Foundations of Behavioural Reseach, 4 edn, Harcourt, Inc. , Philadelphia.

* Kinfu, J 1970, 'The Accounting provisions of the Commercial Code of Ethiopia ', DBA thesis, Michigan State University.

* Kinfu, J, Negash, T \& Merissa, A 1981, 'The Accounting Profession and Practice: The Ethiopian Experience ', paper presented to Regional Conference on Localization of Professional Training, Qualification and Examination in African States, UNECA hall, Addis Ababa, 27-30 June 1981.

* Michael E., Ray, D and Janet, E. (2007), “An improved process model for internal auditing” Managerial Auditing Journal Vol. 22 No. 6, pp. 552-565

* Mihret, DG \& Yismaw, AW (2007), 'Internal audit effectiveness: an Ethiopian public sector case study', Managerial Auditing Journal, vol. 22, no. 5, pp. 470-84.

* Mihret, DG \& Woldeyohannis, GZ (2008), 'Value-added role of internal audit: an Ethiopian case study', Managerial Auditing Journal, vol. 23, no. 6, pp. 567-95.

* Mihret, D (2009), 'Antecedents and organizational performance implications of internal audit effectiveness: evidence from Ethiopia ', Unpublished PhD thesis, University of Southern Queensland, Australia.

* Mihret, DG (2010), 'Factors associated with attributes of internal audit departments: a canonical analysis', African Journal of Accounting, Economics, Finance and Banking Research, vol. 6, no. 6, pp. 42-61.

* Mihret, DG, James, K \& Mula, JM (2010), 'Antecedents and organisational performance implications of internal audit effectiveness: some propositions and research agenda', Pacific Accounting Review, vol. 22, no. 3 , pp. 224-52.

* Ministry of Finance \& Economic Development (2004E.C) Internal Audit Training Module ON the internal audit procedure manual

* MoFED (2004), Internal Audit Standards and Code of Ethics for Internal Auditors and Internal Audit Procedural Manual, MoFED, Addis Ababa

* Ndiwalana (2009); Budgeting Participation Goal Commitment and Employee Performance

* Robins, S.P and Coulter, M. (1999), Management, 6th Ed., New Jersey:prentice - Hall international Inc.

* Rue, Leslie W. \& Byars, Lloyd L. (2005), Management Skills and application, $11^{\text {th }}$ Ed, McGraw-Hill higher Education.

* Senft, Sandra \& Gallegos, Frederick (2009), Information Technology Control and Audit, 3rd Ed, Taylor \& Francis Group, LLC 
* Stewart, J \& Subramaniam, N 2010, 'Internal audit independence and objectivity: emerging research opportunities', Managerial Auditing Journal, vol. 25, no. 4, pp. 328-60.

* Unegbu A, Kida M (2011). Effectiveness of internal audit as instrument of improving public sector management. J. Emerging Trends Econ. Manage. Sci. 2(4):304-309. Retrieved from EBSCO database.

* Vijayakumar A, Nagaraja N (2012). Internal control systems: effectiveness of internal audit in risk management at public sector enterprises. BVIMR Manage. Edge 5(1):1-8. Retrieved from EBSCO database. 